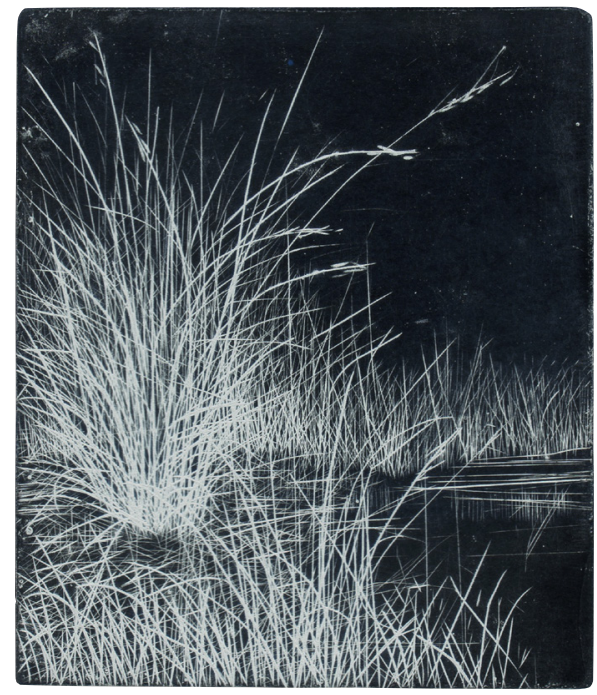




\title{
Ausiàs March agafa la ploma
}

\author{
[Ausiàs March takes up the pen]
}

\author{
Robert Archer \\ King's College London / Universitat de València \\ robert.archer@kcl.ac.uk
}

\begin{abstract}
Resum: S'intenta reconstruir, partint d'observacions de l'època (principalment el Torcimany de Lluís d'Averçó) i altres modernes (sobretot Paul Valéry), el procés composicional probable pel qual Ausiàs March pogué escriure cada nou poema. Es proposa que els primers versos tenen un paper especialment important perquè semblen impulsar la resta de la composició, $\mathrm{i}$ en un cert sentit impliquen tot el que després s'elaborarà d'acord amb les normes vigents de composició retòrica. S'estudien quatre poemes a la llum d'aquestes idees: els XXXIX, XLVI, LVIII i CV.
\end{abstract}

Paraules ClaU: Ausiàs March, poesia segle xv, creació nou poema, primers versos

Aвstract: An attempt is made to construct the probable process by which Ausiàs March wrote a new poem, using as a basis some ideas from his time (in particular Torcimany of Lluís d'Averçó) and others deriving from modern poets (especially Paul Valéry). It is proposed that the first lines of March's poems always have a specially important role to play since it is they that set off the process of creation while they also imply all that is afterwards developed following the rhetorical norms of composition. Four poems are studied in the light of these ideas: XXXIX, XLVI, LVIII i CV.

KEYwords: Ausiàs March, fifteenth century poetry, creation of a new poem, first lines

Recepció: 26/07/2017. Acceptació: 27/09/2017. Publicació: I 5/I2/2017

REVISTA VALENCIANA DE FILOLOGIA / I (20I7) p. 35-60 / ISSN 0556-705X DOI I0.28939/RVF.VIII.I9 
En un cert sentit, quan es publica l'obra completa d'un poeta, com hem fet fa poc en el cas d'Ausiàs March, s'està construint un objecte literari artificial (Archer 2017). Generalment els poetes lírics no treballen un poema pensant en el conjunt dels seus textos escrits i per escriure, sinó en una peça, la que tenen entre mans. En l'acte de creació, els poemes que poden haver escrit abans o escriuran després són en gran part irrellevants, tot i que hi haurà vincles temàtics o estilístics entre tots. El poeta en aquest moment s'enfronta a una sola composició $i$ als problemes que aquesta - i cap altra - li presenta. Àdhuc quan l'autor, a partir d'un cert moment en la seua trajectòria, construeix una obra per a formar un llibre - pensem en el cas de Petrarca o de Walt Whitman o el Martí i Pol del Llibre de les solituds ho fa construint-lo poema a poema (Petrarca 1981, Whitman 1993, Martí i Pol 2000: 95-109). La qüestió és especialment delicada quan es tracta d'una obra de les dimensions de la de March, convertida ja des de fa temps en un imponent monument lingüístic i cultural, sostingut pel pes de tants versos i tantes interpretacions. La recopilació de totes les seues composicions, escrites independentment i en el seu propi moment, si bé és absolutament necessària per a la conservació d'una herència cultural, és nogensmenys un factor decisiu en allunyar-nos encara més de la immediatesa del poema recentment creat. Dit d'una altra manera, si agafem l'obra completa de March i ens posem a llegir el poema a què els editors han donat el número $\mathrm{XLV}$, som sempre conscients dels quaranta-quatre que hem llegit, i els setanta-cinc que estan per llegir: el poema en si es defineix, d'una manera distorsionada, per la seua relació amb els altres cent-vint-i-huit.

En aquest treball voldria proposar que es podria recuperar una part d'aquella immediatesa del nou poema si ens esforcem a reconstruir, fins allà on siga possible, el procés composicional pel qual March pogué arribar a escriure'l. És una aproximació a la seua poesia que s'ha plantejat poques vegades, potser mai, sens dubte perquè ens porta a un terreny que sembla especulatiu. Però crec que és una qüestió important, i ací miraré de demostrar que és menys hipotètica que el que podria pensar-se a primera vista.

REVISTA VALENCIANA DE FILOLOGIA / I (20I7) p. 35-60 ROBERT ARCHER

Ausiàs March agafa la ploma / 36 


\section{Escriure un nou poema}

D’on li sorgia a March la idea d'escriure un poema nou? Per a aproximar-nos a aquesta qüestió convindria consultar en primer lloc dos textos teòrics de l'època sobre la pràctica de la gaia ciència.

En primer lloc, considerem el següent passatge del Prologus Baenensis, el prefaci en prosa que entre 1426 i 1430 escriu Juan Alfonso de Baena per a la seua recopilació de poemes de la segona meitat del segle XIV i el primer quart del xv:

A todos es çierto e notorio que [...] el arte de la poetria e gaya çiençia es una escriptura e compusiçión muy sotil e bien graçiosa, e es dulçe e muy agradable. [...] La qual çiençia e avisaçión e dotrina que d'ella depende e es avida e reçibida e alcançada por graçia infusa del Señor Dios, que la da e la embía e influye en aquel o aquellos que bien e sabia e sotil e derechamente la saben fazer e ordenar e componer e limar e escandir e medir por sus pies e pausas, e por sus consonantes e sílabas e açentos, e por artes sotiles e de muy diversas e singulares nombranças (Dutton i González Cuenca 1993: 9).

Baena enfoca el fenomen de la creació d'un poema en la formació del que el compon i en els seus dots naturals per a la composició, la graçia infusa, per la qual cosa vol dir la predisposició a la creació poètica, conseqüència, com tot el món creat, de la voluntat divina (Weiss 1990: 25-54).

A continuació, Baena s'esplaia sobre la formació del poeta, parlant de l'elevado entendimiento necessari, la mateixa virtut que Santillana alaba en Ausiàs March quan el descriu com d' "assaz elevado spíritu» (Garci-Gómez 1984: 91), una sèrie de qualitats intel-lectuals imprescindibles, una profunda i variada formació, extenses lectures, el tracte amb les més altes esferes de la societat, uns orígens nobles, i el lliurament a l'amor:

E aun assimismo es arte de tan elevado entendimiento e de tan sotil engeño que la non puede aprender ni aver nin alcançar nin saber

REVISTA VALENCIANA DE FILOLOGIA / I (20I7) p. 35-60 ROBERT ARCHER Ausiàs March agafa la ploma / 37 
bien nin como deve, salvo todo omne que sea de muy altas e sotiles invençiones e de muy elevada e pura discreçión e de muy sano e derecho juizio, e tal que aya visto e oído e leído muchos e diversos libros e escripturas e sepa todos los lenguajes, e aun que aya cursado cortes de reyes e con grandes señores e que aya visto e platicado muchos fechos del mundo e, finalmente, que sea noble fidalgo, e cortés e mesurado e gentil e graçioso e polido e donoso, e que tenga miel e açúcar e sal e aire e donaire en su razonar, e otrosí que sea amador e que siempre se preçie e se finja de ser enamorado; porque es opinión de muchos sabios que todo omne que sea enamorado, conviene a saber, que ame a quien deve e como deve e donde deve, afirman e dizen qu'el tal de todas buenas doctrinas ... [es doctado] (Dutton i González Cuenca 1993: 9-10).

Però Baena no diu res sobre el procés pel qual el poeta passa, mitjançant la graçia infusa, a l'acte d'escriure. Es dedueix que per a ell els poemes sorgeixen de la combinació de talent natural i formació intel-lectual i social, una posició concordant amb el seu propòsit de reivindicar per a la gaia ciència i els seus practicants nobles un paper fonamental en la cultura de la cort en la tercera dècada del segle XV (Weiss 1990: 54).

La qüestió de les condicions necessàries per a la composició poètica es planteja d'una manera molt diferent en el segon text que voldria comentar, aquest de les últimes dècades del segle XIV. Al manual retoricopoètic Torcimany, Lluís d'Averçó deixa clar des del principi que el seu voluminós llibre està destinat a animar els homes lletrats a escriure. Anteriorment a Baena, Averçó alaba la gaia ciència com un exercici intel-lectual molt digne de l'home; al·lega a favor d'aquesta activitat que «aprima l'enteniment, [...] adoba la subtilesa [...] i entrica l'enginy» (Averçó 1956: I, 14). Però Averçó escriu des d'un enfocament pràctic, assegurant al novici en la poesia que, amb feina i amb un estudi ben fet del seu manual acabarà competent en aquesta art.

És per això que intenta explicar els passos que s'han de seguir per redactar un nou poema. Primer, el poeta ha de decidir de què vol parlar, i a continuació pensar en quina forma ho farà, forjant en la seua ment una idea clara de com ha de procedir. D’aquesta manera haurà posat en marxa la invenció (la inventio de

REVISTA VALENCIANA DE FILOLOGIA / I (20I7) p. 35-60 ROBERT ARCHER Ausiàs March agafa la ploma / 38 
la retòrica clàssica), que per a Averçó és l'element fonamental. Per això escriu un llarg apartat on mira de definir el procés pel qual el poeta o trobador inventa (o «troba»). Aquest procés comença en la voluntat del poeta d'escriure, passa per la concepció de la matèria que tractarà en la seua obra i acaba en la configuració de la forma genèrica i mètrica que l'obra ha de prendre:

Aquest cap [=apartat] de invenció ha tot son fundament en la imaginació e en la fentesia de l'hom. Eximpli: vos prenetz volentat de fer alguna obra d'aquesta sciència de trobar, la qual volrrets dictar a honor de Déu o de sa gloriosa Mare o de amor o de mal dit o de qualque altra rahó; tot primerament ans que alrre façats vos cové imaginar aquelha matèria de la qual volrrets parlar, per quina forma ne parlarets: si-n parlarets per forma de lleor o de dirrisió o de soplicació o de plant o de interrogació o de demanda o de resposta o de qualque altra forma. E com aquesta imaginació vós haurets haüda, ne l'haurets dins vostra fentesia empremptada, e volrrets parlar d'alguna de las sobreditas cosas, e aquelha matèria de la qual volrrets parlar haurets en vostra imaginació formada per la manera pus prop dita, lavors en vostra fentezia e imaginació serà complit lo primer cap de invenció; e açò per tal com a la matèria de la qual vos volrrets parlar, haurets ja dada forma en vostre enteniment. (Averçó, 1956, I, 27).

La resta del passatge continua de la mateixa manera. Averçó es mostra optimista quant a les possibilitats de qualsevol home lletrat de crear un poema si s'arma de les regles, estudia les formes del vers i de l'estrofa, i disposa d'un diccionari de rims en occitanocatalà com el que hi ha al mateix Torcimany. Escriu per al poeta novell, volent animar els seus contemporanis a practicar la gaia ciència i, sens dubte, a participar en els certàmens poètics fundats per ell i Jaume March el 1393 (Averçó 1956: I, XxIII), però no explica com es pot començar a escriure un poema. En comptes d'això, insisteix en la importància de concentrar-se i no distraure's amb altres coses. No arriba a explicar-ho amb més detall perquè, com ell mateix confessa, manca de les subtilitats (I, 15) necessàries per a fer-ho. No deixa de ser molt interessant que Averçó entenga

REVISTA VALENCIANA DE FILOLOGIA / I (20I7) p. 35-60 ROBERT ARCHER Ausiàs March agafa la ploma / 39 
que tots aquests preparatius són les condicions essencials perquè es produesca el moment de la creació poètica, un moment en què voluntat, matèria i forma conjuntament es posen en marxa i produeixen el poema:

donchs, veu's que havets volentat e matèria formada per obrar, per tal com al primer moment que vós hag[u]és de obrar, ço és, la volentat, acompanya's matèria, e aquelha volentat e matèria en vostra fantasia dóna's forma.

Sembla lògic que March hagués conegut el Torcimany, tenint en compte els vincles entre Averçó i el seu oncle Jaume. El llibre contenia molta matèria que encara era d'una certa importància per a ell i que, de fet, queda reflectida en la seua obra. Però és evident que per a un poeta de tanta ciençia infusa les idees que s'hi esbossen sobre com començar a escriure un dictat, per molt sensates que siguen, no li haurien servit de gran cosa.

Tampoc no li haurien fet falta. Això perquè, com veurem, hi ha bones raons per a creure que a March li passava igual que a molts poetes de totes les èpoques: els poemes, per dir-ho d'alguna manera, venien sols, anunciant-se amb un sol vers o un ritme prosòdic. Ni a través d'un procés rapsòdic o d'un furor poeticus, tampoc del mecànic que descriu Averçó, sinó com una manera de portar allò que entenem per inspiració a la seua plasmació en paraules i formes.

És un procés que descriu Paul Valéry, cinc segles i mig després del Torcimany i servint-se de totes les subtilitats que Averçó potser intuïa, però que a finals del xiv li era impossible expressar perquè no existien els mitjans crítics per a fer-ho. Valéry, tan atent sempre als seus propis processos creatius, parla de l'origen de dos poemes seus:

Mon poème "le Cimetière marin" a commencé en moi par un certain rythme, qui est celui de vers français de 10 syllabes, coupé en 4 et 6 . Je n'avais encore aucune idée qui dût remplir cette forme. Peu à peu des mots flottant s'y fixèrent, déterminant de proche en proche le sujet, et le travail (un très long travail) s'imposa. Un autre poème,

REVISTA VALENCIANA DE FILOLOGIA / I (20I7) p. 35-60 ROBERT ARCHER

Ausiàs March agafa la ploma / 40 
"la Pythie", s'offrit d'abord par un vers de 8 syllabes dont la sonorité se composa d'elle-même. Mais ce vers supposait une phrase, dont il était une partie, et cette phrase supposait, si elle avait existé, bien d'autres phrases. Un problème de ce genre admet une infinité de solutions. Mais en poésie les conditions métriques et musicales restreignent beaucoup l'indétermination. Voici ce qui arriva: mon fragment se comporta comme un fragment vivant, puisque, plongé dans le milieu (sans doute nutritif) que lui offraient le désir et l'attente de ma pensée, il proliféra et engendra tout ce qui lui manquait: quelques vers au-dessus de lui, et beaucoup de vers dessous (Valéry 1944: 161).

Valéry analitza ací el fenomen a què des del segle XIX molts poetes han al-ludit d'una forma o altra: l'aparició inesperada en la ment del poeta d'un vers amb un determinat ritme que, o s'ofereix com el primer de tot el poema o, en posició interior, és el motor creador dels restants versos. En ambdós casos, el vers és el punt de partida del poema i, en un cert sentit, conté tot el que ha de ser en la seua forma final. Podem suposar que aquell vers condensa un procés de meditació sobre un tema o sobre uns sentiments que esperen la seua plasmació en paraules. És, en termes del mateix Averçó, la invenció, però en una forma inconscient. La resta, com també diuen un bon nombre de poetes moderns i no tan moderns, és una labor conscient d'elaboració, seguint el camí ja indicat pel ritme d'un vers sobtadament aparegut.

Un altre testimoni d'aquest procés el trobem en el llibre de Dennis O’Driscoll que recull les seues extenses entrevistes al poeta Seamus Heaney, Nobel de Literatura. Curiosament, Heaney al-ludeix a un concepte, la gràcia de la religió catòlica, potser no tan diferent de la graçia infusa de Baena, però també recalca l'absoluta dependència del ritme del primer vers en la composició del poema:

He adquirit del catolicisme la noció de la gràcia; i és cert que crec que, si no hi ha una certa energia imprevista per a començar, no pots seguir. [...] És una idea que em costaria negar; no sé com he d'escriure un poema fins que no tinga alguna cosa amb què escriure. No pots arrancar si no

REVISTA VALENCIANA DE FILOLOGIA / I (20I7) p. 35-60 ROBERT ARCHER Ausiàs March agafa la ploma / 4 I 
tens un primer vers que ja comença a desenvolupar-se musicalment: no vull dir melodiosament, només que el poema necessita un suport fonètic o una promesa rítmica. ${ }^{1}$

Evidentment, la part inconscient de la creació d'un poema està vinculada a la llarguíssima tradició de la idea de la inspiració o, en certs àmbits, del paper de la musa. No és una invenció del segle XIx, tot i que la poesia romàntica anglesa i la de diversos altres països europeus va aprofitar-la per construir la seua pròpia mitologia poètica. I precisament per l'antiguitat del concepte, amb els seus orígens en la tradició hel-lènica i bíblica, aquest fenomen del vers originari, inesperat pel poeta mateix, no es pot aplicar tan sols a la poesia escrita en els segles moderns, quan s'ha començat a reflexionar sobre els processos mentals de la creació. Efectivament, és un fenomen que es fa palès, i de manera molt notable, en l'obra d'Ausiàs March. L'evidència està en els seus primers versos. Al llarg del temps, sempre s'ha remarcat el poder i la contundència de molts dels seus versos. Ja al segle Xvi els lectors parlaven d'aquesta qualitat i de com augmentava l'impacte sentenciós (i, per tant, moral) de la seua obra. Així Juan de Resa al seu pròleg de l'edició val-lisoletana d'Ausiàs March de 1555:

Parescióme gastar tiempo en esto, por comunicar a mi patria una obra tan provechosa, llena de preceptos de bien vivir, conversar y morir, en la qual, como en un claro espejo, está representada toda la razón de la vida humana. Júntase con esto estar todo este libro lleno de muy graciosos y elegantes dichos, con mucha hermosura y elegancia. No quiero dezir, pues cada uno podrá leer las muchas \& muy graves sentencias que mezcla, los muy agudos dichos de que usa, las muy ingeniosas fábulas que introduze, los muchos lugares que de en medio de la philosophia saca... (March 1555, fol. 3v; Escartí 1999: 191).

1 From Catholicism I acquired the notion of grace; and I do believe that, unless there is a certain unforeseen energy to begin with, you can't proceed. [...] I still can't get away from that; I don't know how to write a poem unless there's something to write a poem with. You can't get started without a first line that goes musically - by which I don't mean melodiously, just that it needs phonetic purchase o rhythmical promise (O’Driscoll 2008: 444). Traducció de R. A.

REVISTA VALENCIANA DE FILOLOGIA / I (20I7) p. 35-60

ROBERT ARCHER

Ausiàs March agafa la ploma / 42 
Martí de Riquer, quatre segles després i amb una valoració més equilibrada, troba que en March «molt sovint, enmig de versos difícils i àrids a l'orella, n'apareixen d'altres de sorprenents, vigorosos, en podríem dir lapidaris...» (Riquer, 1964,III, 222-223).

En aquest article voldria desenvolupar la idea que aquest vers potent, quan és el primer d'un poema i resultat del procés subconscient que descriuen els poetes moderns, li dóna tot el seu impuls, marcant el camí que prendrà la resta de la composició.

\section{Opcions per al desenvolupament del primer vers}

Concebut el primer vers, és el moment en què s'activa tot el bagatge mètric, lingüístic i cultural de March (perquè sense la seua formació, i sense la pràctica que podem suposar que feia constantment, el nou poema moriria al cap de poc de començar). És ara quan, de manera conscient, treballa aquell vers per a ampliar-lo en el novelh dictat de què parla Averçó.

Ara bé, quan componia els seus poemes, March es movia dins d'uns paràmetres determinats $i$ havia d'atendre les convencions literàries del seu temps i els valors literaris que aquestes implicaven, construint-los amb els mitjans d'expressió valorats pels seus contemporanis. Tenia una sèrie de recursos retòrics al seu abast —la hipèrbole, el símil, la metàfora, l'al-legoria, entre molts altres- i els aprofitava tots. Però també havia de tenir en compte les normes de la seua art. Aquests criteris eren molt difosos a la segona meitat del segle XIV i la primera del Xv tant a la Corona d'Aragó com a Castella, per mitjà de les activitats i reunions poètiques a les corts; però també es plasmaven en manuals de preceptiva poètica i retòrica com ara el mateix Torcimany. Només dins d'aquests perímetres el poeta podia exercir la llibertat de ser original, de crear un nou poema.

Al mateix temps, March es mostrava molt atent als vicis que es poden cometre en la poesia (Averçó dedica moltes pàgines a explicar en què consisteixen), i hi al-ludeix diverses vegades, negant que haja incorregut en el vici de

REVISTA VALENCIANA DE FILOLOGIA / I (20I7) p. 35-60

ROBERT ARCHER

Ausiàs March agafa la ploma / 43 
la contradicció, per exemple, o en el del «sobreslaus» (Averçó 1956: 114-175). March havia de ser conscient que part del seu públic era competent a identificar aquests defectes. A les corts on hi havia activitat literària sembla que eren molt aficionats a cultivar aquesta capacitat crítica. Segons Pérez de Guzmán, el mateix rei Joan II de Castella, "oía muy de grado los dizires rimados e conoçía los viçios dellos, avía gran plazer en oír palabras alegres e bien apuntadas, e aún él mesmo las sabía bien dizir» (Pérez de Guzmán 1965: 39). A March li devia importar que es manifestés en cada poema tant la seua originalitat com el seu domini absolut de les normes que regien la composició poètica (sobretot, potser, quan sabia que no les complia).

Quant a l'estructura del poema, s'entenia que aquesta havia de seguir a grans trets la dispositio retòrica comuna: l'exordi amb la seua captatio benevolentiae; la proposició —allò que es volia demostrar-; els arguments i les seues proves (narratio, probatio); i la conclusió (peroratio), potser amb una refutatio en algun moment per a rebutjar un possible argument contrari. Finalment, la tornada, que molt sovint prenia la forma d'un apòstrofe dirigit quasi sempre a una dama, però també de vegades a un senyor o amic (Dragonetti 1960; Archer 2009: 22-34). I precisament perquè March escrivia conscient de l'estructura retòrica de la dispositio sembla dubtós que els abundants versos interiors, per impactants que siguen, poguessen servir de punt de partida, a la segona manera assenyalada per Valéry. Em referesc a versos interiors de March tan potents com ara:

En tot lleig fet hagué lo cor salvatge (LXVIII, 23)

Dolors he tals que en amadors no vénen (XXXV,13)

Lo vici és tant que la virtut ha empesa (XXVI, 17)

Los mals d'amor són pocs al juí comú (XVII, 25)

O bé versos sentenciosos com són:

Molt hom és bo per ésser un catiu que per senyor no valria un clau (CII, 61-62)

REVISTA VALENCIANA DE FILOLOGIA / I (20I7) p. 35-60 ROBERT ARCHER

Ausiàs March agafa la ploma / 44 
Versos com aquests, i així mateix els molts símils en posició interior, serveixen per a reforçar l'impacte de la resta del poema. Però el concepte retòric de l'estructura d'un poema que March tenia converteix en poc probable la possibilitat que servissen com a vers originari de la composició. Aquest paper, amb tota probabilitat, el tenien els versos que ocupen una posició preliminar.

\section{Quatre primers versos i el seus poemes}

Ens quedem, doncs, amb el primer vers com a probable originador del procés de composició del poema. És més que un mer punt de partida perquè marca el to, el ritme, i la direcció en què el poema ha d'anar. En crear un novelh dictat, March desenvolupava el contingut expressiu d'aquest primer vers i li donava forma, d'acord amb les normes i l'estructura establerta segons els cànons de la seua època. En la resta d'aquest treball, a tall d'exemple, veurem detalladament quatre poemes.

El conegut XXXIX apareix a les edicions antigues a partir de la de 1543 al capdavant de tots els altres poemes, sens dubte perquè en la primera cobla semblava parlar en general de la naturalesa de les seues composicions. El primer vers, on dóna a entendre que defineix la seua obra sobre l'amor, s'amplia en l'exordi que ocupa tota la primera estrofa (v. 1-8):

Qui no és trist, de mos dictats no cur, o en algun temps que sia trist estat; e lo qui és de mals passionat, per fer-se trist, no cerque lloc escur; llija mos dits, mostrants pensa torbada, sens alguna art eixits d'hom fora seny. E la raó que en tal dolor m'empeny amor ho sap, qui n'és causa estada.

El poeta invita el lector a recórrer els dictats escrits fins aquell moment i, amb l'ajuda de la seua lectura, lliurar-se a la tristesa. Es declara un foll d'amor

REVISTA VALENCIANA DE FILOLOGIA / I (20I7) p. 35-60

ROBERT ARCHER

Ausiàs March agafa la ploma / 45 
i —no obstant el nivell poètic que es manifesta en cada vers- afirma que escriu sense art.

Però en aquesta primera cobla no explica per què invita els altres enamorats a refugiar-se en la tristesa i a fer-ho mitjançant la lectura dels seus poemes. Això s'aclareix als versos següents (v. 9-12) de la segona estrofa, que de fet són la proposició (propositio) del poema: en la tristesa amorosa hi ha un plaer suprem:
Alguna part, e molta, és trobada
de gran delit en la pensa del trist,
e si les gents ab gran dolor m'han vist,
de gran delit ma arma fon companyada.

Al llarg dels següents vint versos, March s'esforçarà a justificar aquesta proposició, i ho farà per mitjà d'una anàlisi de les seues pròpies experiències, les quals configuren la narratio i la probatio de l'estructura. Quan pensa exclusivament en l'amor, el plaer és tal que perd la consciència de viure en el món; però quan vol profunditzar en l'amor, entén que el plaer es barreja amb el dolor (v. 13-16). Ha arribat a entendre tant el que és l'amor que vol dedicar-s'hi únicament $\mathrm{i}$, tot $\mathrm{i}$ que no renuncia al premi esperat (el de ser amat per la dona estimada), el més gran plaer, fins i tot més gran que aquest premi, consisteix a lliurar-se a la tristesa amorosa (v. 17-24). Això és en part perquè aquest estat comporta el que ell anomena un «delitós llanguiment» (v. 28), però també s'explica pel plaer que, igual que totes les altres formes de tristesa, deriva del sentit de llàstima per si mateix (v. 25-32).

Arribat a aquest punt, March introdueix una refutatio. Reconeix que la gent podria reprendre'l per l'actitud malsana que els seus versos tant alaben. Anticipant aquestes objeccions, explica que, si busca el sofriment de l'amor, és perquè sense aquest no hi ha plaer:

Ésser me cuid per moltes gents représ, puis que tant llou viure en la vida trista, mas jo, qui he sa glòria a l'ull vista, desig sos mals, puis delit hi és promés (v. 33-36)

REVISTA VALENCIANA DE FILOLOGIA / I (20I7) p. 35-60 ROBERT ARCHER Ausiàs March agafa la ploma / 46 
En els següents versos (v. 37-40), a manera de peroratio o conclusió, insisteix que només els que han experimentat directament l'intens plaer de la tristesa que acaba de descriure poden entendre de què està parlant. Així, enllaça amb el punt de partida de tot el poema, el seu primer vers. En la tornada (v. 41-44), dirigint-se a «Llir entre cards», resumeix la seua condició d'amant com la d'algú que viu entre els extrems de gran tristesa i gran plaer.

Sembla probable que aquest XXXIX siga representatiu de la majoria dels poemes, almenys de les nombroses composicions breus adreçades a una dama $\mathrm{o}$ a la figura personificada de l'amor: en aquest es desenvolupa el discurs que està implícit en el primer vers que és el seu punt de partida i el seu origen.

El segon poema que analitzarem, el LVIII, respon a un model diferent. Ací el primer vers, que dóna l'impuls a tota la composició, ho fa mitjançant la imatge d'un símil del qual és el començament:

Sí com lo ric que per son fill treballa, e sol per ell vol que l'haver servesca, e quan la mort vol quell fill jorns fenesca, dóna sos béns, e tot goig de si talla,

Aquest primer vers porta el poema cap a uns referents (un home ric, el fill, la mort, la desesperació) que evidentment no es relacionen directament amb el jo poètic que es proclama, per exemple, al vers 1 del poema anterior, el XXXIX. No sembla estar parlant de si mateix sinó d'un altre. La primera frase comparativa ( «Sí com») de quatre versos és part d'una estructura analògica que s'aclareix més avall als v. 5-8:

ne pren a me, qui llanç tot mon delit, perdent a vós, lo goig de mon entendre, car mon voler en àls no pot entendre, ans tota res m'és enuig e despit.

Però en realitat el que expliquen aquests versos sobre la situació del poeta és només un aclariment parcial del sentit analògic que la imatge sembla

REVISTA VALENCIANA DE FILOLOGIA / I (20I7) p. 35-60 ROBERT ARCHER Ausiàs March agafa la ploma / 47 
contenir. De seguida entenem que l'home ric correspon al poeta, el fill a la dama, i el goig de l'home ric al que sent el poeta davant la dama. Amb això March ha establert la propositio del poema: que només l'amor de la dona el pot satisfer. En canvi, no rep cap explicació analògica el concepte contingut als primers dos versos: el de treballar amb la fi d'adquirir un gran patrimoni per al fill (per a la ment medieval els fills eren un altre bé material com March deixa ben clar a XCV, 17-18), tot i que en podem deduir la idea implícita de la recompensa que el poeta no ha rebut pels seus sofriments amorosos per la dama. No és l'únic concepte que queda per resoldre: la situació de l'home ric també posseeix unes connotacions morals perfectament d'acord amb el sentit de molts dels seus poemes d'amor, sobretot els de «Llir entre cards». Així, els primers dos versos al-ludeixen a una veritat moral diverses vegades repetida: si tot li resulta enutjós al poeta és perquè ha comès l'error de depositar les seues esperances en l'amor d'una dona.

Aquesta dimensió moral sembla confirmar-se als v. 9-12, on March revela que el seu amor pren la forma del desig físic. En les següents estrofes, corresponents a la narratio i probatio retòriques, desenvolupa la descripció de la seua absoluta dedicació a la dama, un estat en què, segons afirma, raó i desig estan perfectament reconciliats (v. 25-32). Als v. 28-32 utilitza algunes connotacions de la imatge preliminar quan declara, identificant-se amb el fill de l'home ric, que ha eixit "d'un ventre trist», i als v. 33-40 insisteix en com viu entre els extrems de poca esperança i gran desig, incapaç de trobar el «mig», el lloc aristotèlic de l'equilibri moral que és una constant del llenguatge de March.

La tornada també serveix de peroratio o conclusió:

Llir entre cards, delits d'amor estan partits segons d'on surt la voluntat; algú d'ells mor ab lo desig finat; altre delit perdurable roman.

Al final, la dimensió moral, que era només un element implícit i sense resoldre de la imatge que ha donat l'impuls inicial al poema, es posa de manifest:

REVISTA VALENCIANA DE FILOLOGIA / I (20I7) p. 35-60 ROBERT ARCHER Ausiàs March agafa la ploma / 48 
només l'amor espiritual pot oferir un plaer que perdure, no el tipus d'amor que ha declarat en les estrofes anteriors.

Aquesta capacitat de la imatge d'un símil, quan se situa al capdavant d'un poema, d'introduir un nivell de sentit secundari es troba en més casos. De fet, tots els símils llargs de March, tant els que estan en posició inicial com els interiors, són un recurs extraordinari en la seua obra, que ell explota plenament. Aquest recurs és potser la major d'aquelles subtilitats, l'existència de les quals Averçó reconeix però no se sent capaç d'explicar (Archer 1985 passim i 2009: 117-134). Els 109 símils llargs (amb imatges d'almenys quatre versos) utilitzats per March en aproximadament vuitanta dels 129 poemes que se li atribueixen, junt amb les seixanta-vuit comparacions amb imatges de dos versos, funcionen com a elements del discurs de manera sorprenent. No sols expliquen o aclareixen el significat establert en la resta de l'estrofa on apareix el context explícit, o simplement afegeixen una càrrega emocional al que es diu, sinó que, de fet, estan pensats per a tenir un ventall complet de funcions. Freqüentment se'ls assigna les següents tasques: prefigurar l'ocasió del poema, que es revela més endavant en la tornada (i aquesta és una funció en si mateixa sota la qual s'han de subsumir diversos objectius poètics); convèncer el lector d'un determinat punt de vista utilitzant mitjans que inclouen l'argument sofístic; desviar la responsabilitat moral del poeta d'una manera que porta el lector a qüestionar l'aparent distància de la veu moral; o contradir rotundament la pròpia advocació esporàdica pel poeta de l'amor sensual; i, finalment, com en el cas del LVIII, introduir una perspectiva moral on cap altra és evident. Els símils funcionen amb aquests resultats, i per això és fonamental tenir en compte que el seu significat no es limita a l'estrofa en la qual apareixen sinó que s'estén, amb diferents nivells d'èmfasi, al llarg de tot el poema. Afecten el seu significat global, i més encara quan apareixen en posició inicial.

Analitzem ara el poema més conegut de March, el XLVI. Comença amb "Veles e vents han mos desigs complir», un vers que, com veurem, a March li va resultar irresistible. Com en tots els poemes, el primer vers és part de l'exordi. Normalment, aquesta part de l'estructura retòrica és d'extensió limitada: al XXXIX hem vist que ocupa la primera estrofa, i al LVIII es desenvolupa només als v. 1-6. En aquest, en canvi, el seu magnífic primer vers aboca el poema a vint versos d'exordi:

REVISTA VALENCIANA DE FILOLOGIA / I (20I7) p. 35-60 ROBERT ARCHER

Ausiàs March agafa la ploma / 49 
Veles e vents han mos desigs complir

faent camins dubtosos per la mar.

Mestre i ponent contra d'ells veig armar:

xaloc, llevant los deuen subvenir

ab llurs amics lo grec e lo migjorn,

fent humils precs al vent tramuntanal

que en son bufar los sia parcial

e que tots cinc complesquen mon retorn.

Bullirà 1 mar com la cassola en forn, mudant color e l'estat natural,

e mostrarà voler tota res mal

que sobre si atur un punt al jorn.

Grans e pocs peixs a recors correran

e cercaran amagatalls secrets;

fugint al mar on són nodrits e fets,

per gran remei en terra eixiran.

Los pelegrins tots ensems votaran

e prometran molts dons de cera fets;

la gran paor traurà al llum los secrets

que al confés descoberts no seran.

El gran encert del poema és precisament aquest extens i trepidant exordi amb la seua descripció hiperbòlica d'una escena apocalíptica que recull alguns del signes tradicionals de la fi del món. El poeta es projecta com a protagonista en l'escena que descriu i procura, d'aquesta manera, aconseguir la bona disposició de la dama a més d'impressionar el seu públic. És una llarga captatio benevolentiae retòrica que encara enganxa lectors (i oients de la versió musicada de Raimon) avui en dia.

És només en aquest punt, ja en el v. 21, quan March introdueix la propositio del poema i desenvolupa la resta de l'estructura retòrica. L'enuncia als v. 21-24, lligant-la a la imatge de l'exordi mitjançant una referència al perill del viatge apocalíptic:

REVISTA VALENCIANA DE FILOLOGIA / I (20I7) p. 35-60

ROBERT ARCHER

Ausiàs March agafa la ploma / 50 
En lo perill no·m caureu de l'esment, ans votaré al Déu qui·ns ha lligats de no minvar mes fermes voluntats e que tots temps me sereu de present.

A continuació, ve la part central (v. 25-56), la narratio i probatio que es desenvolupen a partir de la proposició. El poema, que ha tingut un començament extraordinari, es va convertint en una composició del tot convencional. Com explica en la peroratio o conclusió dels v. 51-56, només aspira a tenir l'oportunitat de demostrar la força dels seus sentiments, i que està disposat a arribar a tots els extrems per tenir-la (és «el pus extrem amador», v. 41). Afirma que vol deixar les paraules dels seus poemes per a passar a l'acció:

lladoncs les gents no·ls calrà donar fe al que amor fora mi obrarà;

lo seu poder en acte·s mostrarà

e los meus dits ab los fets provaré (v. 53-56)

Però en la tornada confessa que, ja que ordalies com les que descriu als v. 1-20 no es donen en el món real, es troba en una situació d'absoluta impotència davant el futur, víctima de la força dels seus propis sentiments:

Amor, de vós jo·n sent més que no·n sé,

de què la part pijor me'n romandrà, e de vós sap lo qui sens vós està.

A joc de daus vos acompararé.

En tota aquesta part central i final del poema aquella primera imatge apocalíptica quasi s’oblida del tot. Només hi ha la breu al·lusió (v. 51-52) al desig del poeta de tenir l'oportunitat de sotmetre's a una dura prova d'amor:

A mi no plau ma vida ser estorta

d'un cas molt fer, qual preg Déu sia tost.

REVISTA VALENCIANA DE FILOLOGIA / I (20I7) p. 35-60

ROBERT ARCHER

Ausiàs March agafa la ploma / 5 I 
Per aquestes raons, "Veles e vents» és insòlit a l'obra de March: arranca d'un primer vers, com tots els altres poemes, però aquest vers dóna lloc a un exordi extensíssim que domina tota la composició, mentre que la resta de les seues parts retòriques, degudament desenvolupades d'acord amb les normes de la dispositio, queda relegada a un paper secundari. Aquesta capacitat de variació de la pràctica habitual i de les normes és el que distingeix sempre la «invenció» de March davant el repte de convertir el primer vers en un poema. Recordem, per exemple, els casos extraordinaris del poemes XXVI, XXXI i XXXII on March decideix desenvolupar tres formes diferents de discurs moral abstracte, però dóna a cada un final inesperat: les tornades són de tema amorós, sense cap vincle amb la part anterior (Archer 1996: 89-108). March estava molt acostumat a rompre les expectatives formals.

Aquesta capacitat rompedora té el seu màxim exponent al poema $\mathrm{CV}$, el «Cant espiritual», l'estructura del qual comentarem per acabar.

El començament pren la forma d'una premissa:

Puis que sens tu algú a tu no basta.

Com hem explicat en un estudi anterior (Archer 2009: 81-100), aquest vers conté un concepte clau en el conjunt confús i embolicat d'idees que en l'època de March diversos poetes del Cancionero de Baena i autors de tractats en prosa s'havien esforçat per aclarir. Tant el debat poètic del cançoner com els arguments propagats als tractats demostren la manca de consens a Castella i la Corona d'Aragó de la primera meitat del segle xv pel que fa als problemes principals sorgits arran de l'evidència bíblica de la predestinació. No hi ha cap acord general sobre com conciliar la presciència amb l'omnipotència divines, la voluntat de salvació universal amb la creació dels presçits (els que irremeiablement estaven destinats a condemnar-se), o el lliure albir amb la voluntat divina. Tots els textos deixaven clar que el problema de la salvació es reduïa a l'operació de la gràcia: sense un acte específic de Déu, ningú no podria salvar-se.

Al seu poema, March s'enfronta a diverses de les qüestions relacionades amb aquesta idea: la predestinació, la justificació, l'omnisciència divina, el lliu-

REVISTA VALENCIANA DE FILOLOGIA / I (20I7) p. 35-60 ROBERT ARCHER

Ausiàs March agafa la ploma / 52 
re albir, el paper del penediment, l'amor a Déu i l'aparent injustícia de què el pecador sol acusar a Déu. Però no considera totes aquestes idees mitjançant un discurs objectiu i des d'una perspectiva fixa com en diversos poemes de tema moral (per exemple, els CIV, CVI o CXII) sinó que les tracta com a problemes de rellevància personal urgent. Des d'aquesta urgència considera tres aspectes principals pel que fa al destí de la seua pròpia ànima: Com pot arribar a tenir el necessari amor per Déu? És preferible continuar vivint i així potser merèixer el cel per les bones accions que podria realitzar, o morir ja per no carregar la seua ànima amb més pecats encara? Existeix realment la possibilitat que un home tan pecador com ell es puga salvar?

La seua actitud va canviant al llarg del poema. Això és una característica que no caldria esperar d'un poema del s. Xv: la destacada absència de coherència discursiva. Res a veure, per descomptat, amb una composició escrita d'acord amb les nocions retòriques d'estructura com les que caracteritzen les obres d'amor. El «Cant espiritual» sembla, a primera vista, inconnex. Però, si el llegim sense prejudicis, la seua forma irregular es revela com el resultat d'un esforç deliberat per tal de construir un monòleg dramàtic a partir de la forma clàssica de l'oració literària (Archer 1982). És imprescindible, per a l'impressionant versemblança del poema, que els canvis d'estat d'ànim o de perspectiva no estiguen assenyalats de forma convencional. En lloc d'escriure post factum, March documenta la seua crisi espiritual com si aquesta estigués succeint durant el mateix acte de redacció. El resultat és una mena de trajectòria emocional viva, on les úniques fites són els canvis d'ànim en considerar diferents aspectes de la problemàtica de la salvació. D'aquesta manera, el poema sembla dividit en sis blocs, en cada un dels quals es distingeixen canvis d'actitud, quasi sempre abruptes. Així, passa de la por de l'infern (v. 1-80) a una sèrie de dubtes sobre la conveniència o no de morir aviat (v. 81-104), unes afirmacions dogmàtiques sobre la supremacia de Déu (v. 105-144) amb un to d'optimisme que desapareix als v. 145-192, però on es troba l'expressió del desig d'amar més a Déu, la tornada al pessimisme d'abans (v. 193-208), on lamenta el fracàs de la imaginació humana per fer-se una idea adequada de l'infern, i l'últim bloc, on torna a assumir la responsabilitat moral pels seus pecats (v. 209-224) (Archer 1996: 17-47).

REVISTA VALENCIANA DE FILOLOGIA / I (20I7) p. 35-60 ROBERT ARCHER Ausiàs March agafa la ploma / 53 
Són vint-i-vuit estrofes de crisi espiritual dramatitzada que han nascut directament del primer vers, el qual condensa en una premissa la problemàtica complexa que després es desenvolupa al llarg del poema. Cap altre vers del poema -i n'hi ha molts que tenen una gran força- podia haver fet el mateix paper activador.

\section{Conclusió}

Això són només quatre mostres de la funció creadora que té sempre el primer vers en els poemes d'Ausiàs March, marcant-ne la tonalitat i aportant-hi unes ressonàncies semàntiques que se sentiran d'una manera o altra al llarg de les restants estrofes.

En la meua opinió, aquest aspecte de la seua obra és fonamental en el conjunt de qualitats úniques que el distingeix en el panorama de la poesia de les Espanyes del segle xv. March se'ns perfila com el primer gran poeta en llengua autòctona i no simplement un senyor més de la multitud que escrivia versos amb més o menys encert, o fins i tot amb gran competència, com ara Gómez Manrique (Gómez Manrique 2003). Si ens sembla un poeta de debò, amb aquella vigència de què parlava Fuster (1995), no és tan sols perquè dins del seu concepte de l'art cada dictat s'havia d'elaborar intel-lectualment de la manera que explica Averçó. Més aviat propose que hi ha bones raons per creure que és perquè March posava tota la seua gran mestria al servei d'un primer vers que s'havia concebut mitjançant el mateix procés subconscient i imprescindible de què parlen els grans poetes moderns.

REVISTA VALENCIANA DE FILOLOGIA / I (20I7) p. 35-60

ROBERT ARCHER

Ausiàs March agafa la ploma / 54 


\section{Bibliografia}

Archer, R. (1982) “'E ja en mi alterat és l'arbitre': Dramatic Representation in Ausiàs March's Cant Espiritual», Bulletin of Hispanic Studies, 59: 317-323.

- (1985) The Pervasive Image. The Role of Analogy in the Poetry of Ausiàs March, Amsterdam/Filadèlfia, John Benjamins.

- (1996) Aproximació a Ausiàs March. Estructura, tradició, metàfora, Barcelona, Empúries.

- (2009) Lo cor salvatge: indagacions sobre Ausiàs March, València, Institució Alfons el Magnànim.

— (2017) (ed.) Ausiàs March. Dictats/Obra completa, Madrid, Cátedra (col. «Letras Hispánicas»).

Averçó, L. D' (1956) 'Torcimany' de Luis de Averçó. Tratado retórico gramatical y diccionario de rimas, 2 vol., ed. José María Casas Homs, Barcelona, CSIC, 1956.

DragonetTi, R. (1960) La Technique poétique des trouvères dans la chanson courtoise: contribution à l'étude de la rhétorique médiévale, Bruges, De Tempel.

Dutton, B. i González Cuenca, J. (ed.) (1993) Cancionero de Juan Alfonso de Baena, Madrid, Visor.

EsCARTí, J. V. (1999) «Encara sobre València i Ausiàs March al segle XVI», dins R. Alemany (ed.), Ausiàs March i el món cultural del segle Xv, Alacant, Universitat d'Alacant, Institut Interuniversitari de Filologia Valenciana, p. 173-197.

Fuster, J. (1995) «Vigència d'Ausiàs March», dins Misògins i enamorats, ed. Albert Hauf, València, Bromera.

Garci-Gómez, M. (1984) Marqués de Santillana. Prohemios y cartas literarias, Madrid, Editora Nacional.

Gómez Manrique (2003) Cancionero, ed. F. Vidal González, Madrid, Cátedra.

March, A. (1555) Las obras del poeta mossen Ausias March, corregidas de los errores que tenian. Sale con ellas el vocabulario de los vocablos en ellas contenidos [...], Valladolid, Sebastián Martínez.

Martí i Pol, M. (2000) Què és poesia?, Barcelona, Empúries.

O’Driscoll, D. (2008) Stepping Stones. Interviews with Seamus Heaney, Londres, Faber \& Faber. Petrarca, F. (1981) I Sonetti del Canzionere/Los sonetos del Cancionero, Barcelona, Bosch. Pérez de Guzmán, F. (1965) Generaçiones y semblanzas, ed. R. B. Tate, Londres, Tamesis. Riquer, M. DE (1964) Història de la literatura catalana, III, Barcelona, Ariel.

VAléry, P. (1944) «Poésie et pensée abstraite», dins Variété, V, París, Gallimard, p. 129-162. Weiss, J. (1990) The Poet's Art. Literary Theory in Castile c. 1400-60, Oxford, Medium Aevum Monographs.

Whitman, W. (1993) Leaves of Grass. The "Death-Bed" Edition, Nova York, The Modern Library.

REVISTA VALENCIANA DE FILOLOGIA / I (20I7) p. 35-60

ROBERT ARCHER

Ausiàs March agafa la ploma / 55 


\section{APÈNDIX \\ Classificació provisional dels primers versos de March}

Aquest estudi sorgeix de l'observació del gran impacte dels primers versos de March i d'una reflexió posterior sobre el seu paper en la creació del poema. Per si de cas serveix per a aprofundir més en el tema, incloc ací una llista completa dels primers versos (deixant de banda els de circumstància CXXIVCXXVI i el problemàtic CXXVIII), agrupats en blocs segons criteris que es veuran a continuació.

1. En el primer grup hi ha 17 poemes on el primer vers inicia també un símil llarg que marcarà de maneres variades les pautes del desenvolupament temàtic (Archer 1985 i 1996: 149-200):

Així com cell qui desija vianda (IV)

Així com cell qui en lo somnixs delita (I)

Així com cell qui-s parteix de sa terra (CXI)

Així com cell quixs veu prop de la mort (LXXXI)

Lo viscaí que-s troba en Alemanya (CI)

Noxm pren així com al petit vailet (LXVIII)

Pren-me enaixí com al patró que en plaja (II)

Sí col malalt que.l metge lo fa cert (LIX)

Sí col malalt qui llong temps ha que jau (LXXXIII)

Sí com aquell qui, per sa 'nfinitat (L)

Sí com lo ric que per son fill treballa (LVIII)

Sí com lo taur se'n va fuit pel desert (XXIX)

Sí com rictat no porta béns ab si (VII)

Sí com un rei, senyor de tres ciutats $(\mathrm{X})$

Tal só com cell qui pensa que morrà (LI)

Tot llaurador és pagat del jornal (LXXX)

Tot metge pren càrrec de consciença (XLIV).

Cal afegir dos primers versos més amb comparacions superlatives (mitjançant les quals el poeta afirma que el seu cas supera el de l'objecte comparat):

REVISTA VALENCIANA DE FILOLOGIA / I (20I7) p. 35-60

ROBERT ARCHER

Ausiàs March agafa la ploma / 56 
Ab tal dolor com l'esperit s'arranca (LIII)

Cervo ferit no desija la font (LXXXIX)

2. Un segon grup el formarien 12 poemes que arranquen d'un apotegma que de vegades s'estén al segon vers o a tota l'estrofa:

A mal estrany és la pena estranya (XLIX)

Algú no pot haver en si poder (LXVI)

Aquell ateny tot quant atényer vol (CIII)

Cell qui d'altrui rep enuig e plaer (XL)

La vida és breu e l'art se mostra llonga (CXIII)

L'home pel món no munta en gran valer (XXXII)

Lo cinquén peu del moltó ab gran cura (CXVII)

Lo tot és poc ço per què treballam $(\mathrm{CVI})$

Malament viu qui delit perd de viure (LXXXVIII)

Malventurós no deu cercar ventura (XIV)

Qual serà aquell que fora si mateix (CII)

Qui de per si ne per Déu virtuts usa (CIV)

3. El tercer grup inclouria tres poemes que comencen amb una afirmació deductiva o una premissa:

Puis me trob sol en amor, a mi sembla (XCIV)

Puis que sens tu algú a tu no basta (CV)

Puix me penit, senyal és cert que baste (CXV)

4. Al quart grup hi hauria sis composicions que comencen amb un sintagma hipotètic ( «Si...») o adversatiu («Si bé...»):

Si bé mostrau que mi no avorriu (XXXVIII)

Si Déu del cos la mia arma sostrau (XVII)

Si en algun temps me clamí sens raó (CXX)

$\mathrm{Si} \cdot \mathrm{m}$ demanau lo greu turment que pas (LXXXVI)

Si per null temps creguí ser amador (XCVII)

Si prés grans mals un bé·m serà guardat $(\mathrm{XV})$

REVISTA VALENCIANA DE FILOLOGIA / I (20I7) p. 35-60

ROBERT ARCHER

Ausiàs March agafa la ploma / 57 
5. Cinc poemes formarien part del cinquè grup on el vers pren la forma d'una pregunta retòrica («Qui...?»):

Qui és aquell qui en amor contemple (LXXV)

Qui·m mostrarà la fortuna lloar (LXII)

Qui.m tornarà lo temps de ma dolor (LXIII)

Qui serà aquell del món superior (XCIII)

Qui, sinó foll, demana si m'enyor (LIV)

6. Al sisè grup, set poemes més repeteixen sintagmes que expressen quantitat amb «tant», «tots» $\mathrm{i}$ «molt»:

Tant en amor ma pensa ha consentit (XXI)

Tant he amat que mon grosser enginy $(\mathrm{V})$

Tant he amat que vinc en desamar (LXXXIV)

Tots los delits del cos he ja perduts (CXXIIa)

Tots los desigs escampats en lo món (XXXIV)

Molt he tardat en descobrir ma falta (VI)

Molt me par bo que pens de l'altre món (CXXI)

7. Inclouríem en aquest últim grup, el més nombrós, tots aquell primers versos que presenten característiques lèxiques o sintàctiques úniques:

Ab vós me pot amor ben esmenar (XLVIII)

Adéu-siau, vós, mon delit (CXXVII)

Alguns passats donaren si a mort (XX)

Als fats coman tot quant serà de mi (LXXIV)

Alt e amor, d'on gran desig s'engendra (III)

Amor se dol com breuement jo no muir (IX)

Aquelles mans que jamés perdonaren (XCII)

Aquesta és perdurable dolor (XCIX)

Bé.m maravell com l'aire no s'altera (XLVIII)

Callen aquells que d'amor han parlat (XXII)

Cert és de mi que no me'n cal fer compte (CXVI)

Clamar no•s deu qui mal cerca e troba (LII)

REVISTA VALENCIANA DE FILOLOGIA / I (20I7) p. 35-60

ROBERT ARCHER

Ausiàs March agafa la ploma / 58 
Clar és e molt a tots los amadors (LXIX)

Cobrir no puc la dolor qui·m turmenta (CXII)

Colguen les gents ab alegria festes (XIII)

Coratge meu, a pendre esforç molt tard (XLIII)

Dona, si us am, no·m graescau amor (CIX)

En aquell temps sentí d'amor delit (XCI)

Entre amor só portat e fortuna $(\mathrm{C})$

Fantasiant, amor a mi descobre (XVIII)

Ja de amor tèbeu jamés no sia (LXVII)

Ja no esper que sia amat (XII)

Ja tots mos cants me plau metre en oblit (LVIII)

Jo crit lo bé si en algun lloc lo sé (XXVI)

Junt és lo temps que mon goig és complit (XVI)

La gran dolor que llengua no pot dir (XCVI)

La mia por d'alguna causa mou (XXXVII)

Lla só atés d'on só volgut fugir (CX)

Lleixant a part l'estil dels trobadors (XXIII)

Lleixe la sort lo seu variat torn (LXXXV)

Lo jorn ha por de perdre sa claror (XXVIII)

Lo temps és tal que tot animal brut (LXIV)

Los ignorants amor e sos exemples (XLV)

Ma voluntat amant-vos se contenta (LVI)

Maleit lo jorn que $m$ fon donada vida (CXIX)

Mentre d'amor sentí sa passió (CXXIII)

Mes voluntats, en gran part discordants (LX)

Molts hòmens oig clamar-se de fortuna (XXXI)

Mon bon senyor, puix que parlar en prosa (CXXIIb)

No cal dubtar que sens ulls pot hom veure (CXVIII)

No guard avant ne membre lo passat (LXXVIII)

No·m clam d'algú que en mon mal haja colpa (CVIII)

Noxm fall record del temps tan delitós (XXV)

No pens algú que m'allarg en paraules (LXXIII)

No pot mostrar lo món menys pietat (LXXVII)

No sec lo temps mon pensament immoble (XXIV)

No•s maravell algú perquè m'enyor $(\mathrm{XC})$

REVISTA VALENCIANA DE FILOLOGIA / I (20I7) p. 35-60

ROBERT ARCHER

Ausiàs March agafa la ploma / 59 
No só gosat en demanar mercé (LXV)

Oh fort dolor, jo·t prec que mi perdons (LXI)

Oh mort, qui est de molts mals medecina (XXXVI)

Oh quant és foll qui tem lo forçat cas (CVII)

Oh vós, mesquins, qui sots terra jaeu (LXXIX)

Oïu, oïu, tots los qui bé amats! (XIX)

On és lo lloc on ma pensa repose? (LXXVI)

Paor no·m sent que sobreslaus me vença (LXXII)

Per lo camí de mort he cercat vida (XCVIII)

Per molt amar ma vida és en dubte (LV)

Perqué m'es tolt poder deliberar (LXX)

Por de pijor a molts fa pendre mort (LVII)

Quan plau a Déu que la fusta peresca (LXXXII)

Quant més amau, tant més temor teniu (CXXVI)

Què m'ha calgut contemplar en amor (LXXI)

Què val delit, puis no és conegut (XCV)

Qui no és trist, de mos dictats no cur (XXXIX)

Quins tan segurs consells vas encercant (XI)

Retinga'm Déu en mon trist pensament (CXIV)

Sens lo desig de cosa deshonesta (XXXIII)

Sia cascú per ben oir atent (XXXV)

Sobresdolor m'ha tolt l'imaginar (XXVII)

Tot entenent amador mi entenga (LXXXVII)

Veles e vents han mos desigs complir (XLVI)

Vengut és temps que serà conegut (XXX)

Volgra ser nat cent anys o pus atràs (XLI)

Vós qui sabeu de la tortraxl costum (XLII)

Una última observació: com pot comprovar-se per la gran quantitat d'entrades en el setè grup, March recorria molt poc a les frases formulàries per escriure un primer vers. Fins i tot els versos del primer grup que comencen amb un símil utilitzen diverses variants de la primera frase comparativa. Sens dubte, un estudi comparatiu de l'accentuació dels versos revelaria altres trets comuns. ${ }^{2}$

2 Agraesc l'inestimable ajut d'Ana de Miguel i Víctor Labrado en la redacció de la versió final d'aquest article.

REVISTA VALENCIANA DE FILOLOGIA / I (20I7) p. 35-60

ROBERT ARCHER

Ausiàs March agafa la ploma / 60 